\title{
Application of Different Methods of Multicriteria Analysis for Railway Route Selection
}

IVONA Z. NEDEVSKA, University Ss Cyril and Methodius, Faculty of Civil Engineering, Skopje, Macedonia

ZORAN M. KRAKUTOVSKI, University Ss Cyril and Methodius, Faculty of Civil Engineering, Skopje, Macedonia

ZLATKO S. ZAFIROVSKI, University Ss Cyril and Methodius,

Faculty of Civil Engineering, Skopje, Macedonia
Original scientific paper

UDC: 625.11

DOI: 10.5937/tehnika1706797N

Decision making is the study of identifying and choosing alternatives to find the best solution based on different factors and considering the decision makers expectations. Every decision is made within a decision environment, which is defined as the collection of informations, alternatives, values and preferences available at the time when the decision must be made. The difficult point in decisionmaking is the multiplicity of the criteria set for judging the alternatives. The objectives are usually conflicting and, in most of the cases, different groups of decision-makers are involved in the process. To facilitate this type of analysis, a family of tools referred to as Multi - criteria decision - making methods gained ground due to the need to have a formalized method to assist decision - making in situations involving multiple criteria.

This paper presents a methodology for route selecting in the planning and designing of railways based on the multiple criteria decision making. The need for applying multi criteria analysis in the decision making process for studying and designing a transport infrastructure project is also conditioned by the characteristics of the infrastructure that has the title of the public good (many interested subjects for it) and in order to minimize the problems and risks which are related to the elaboration of such projects. The proposed methodology provides a complete and systematic solution to this problem. Result of the methodology is the most suitable route in accordance with the adopted criteria and existing constraints. The developed methodology is based on three different methods for multiple criteria decision making, Weighted Sum Model - WSM, AHP method (Analytic Hierarchy Process) and VIKOR method. Evaluation is performed in section of railway route of two alternatives on the Corridor 10, on the section from station Dracevo (Skopje) and station Veles. The results confirm validity and usefulness of this methodology.

Alternative I is new corridor on the left side of the Vardar Valley, with a minimal radius $R=1.500 m$. the route passes through the villages Oreshani, Taor and Katlanovo. The track is designed for speed of $160 \mathrm{~km} / \mathrm{h}$. Alternative II is a new corridor near variant I, except for the section between the chainage $\mathrm{km} 16$ to $\mathrm{km} 29$, with a minimum radius $R=800 \mathrm{~m}$, in order to minimize earthworks as well as the length of the objects (bridges, viaducts, tunnels) wherever possible. The track is designed according to the speed of $120 \mathrm{~km} / \mathrm{h}$.

Key words: planning and designing, railway route, the most suitable route alternative selection, multicriteria decision making, Weighted Sum Model, Analytic Hierarchy Process, VIKOR method

\section{INTRODUCTION}

Multi-Criteria Decision Analysis, or MCDA, is a

Author's addres: Ivona Nedevska, University Ss Cyril and Methodius, Faculty of Civil Engineering, Skopje, Partizanski odredi 24, Macedonia

e-mail: ivona.nedevska@live.com

Paper received: 30.05.2017.

Paper accepted: 04.12.2017. valuable tool that we can apply to many complex decisions. It is most applicable to solving problems that are characterized as a choice among alternatives.

It has all the characteristics of a useful decision support tool: It helps us focus on what is important, is logical and consistent, and is easy to use.

Generally, when selecting a conveyance system, the usual procedure is to search for a solution by considering various variants. The most frequently 
applied selection methods are based on the technicaleconomic and multi-criteria analysis. In the case the multi-criteria decision-making is applied, the results of the technical-economic analysis (specific costs) are treated as one of the criteria.

The developed methodology is based on three different methods for multiple criteria decision making, Weighted Sum Model - WSM, AHP method (Analytic Hierarchy Process) and VIKOR method.

For successful application of these methods in practice, usually are adopted the following criteria:

- Investments for the construction,

- Management and maintenance cost,

- Capacity,

- Duration of construction works,

- Impact on environment.

In the table below are shown all the criteria that are taken into account when making this multi - criteria analysis, and each criteria is expressed in his natural scale.

\section{Table 1. Criteria in natural scale}

\begin{tabular}{|c|c|c|c|c|c|}
\hline \multirow{4}{*}{ Alternative } & \multicolumn{5}{|c|}{ Criteria } \\
\cline { 2 - 6 } & $\begin{array}{c}\text { Construction } \\
\text { Investments }\end{array}$ & $\begin{array}{c}\text { Cost } \\
\text { management } \\
\text { and } \\
\text { maintenance } \\
\text { of the route }\end{array}$ & Capacity & $\begin{array}{c}\text { Duration of } \\
\text { construction } \\
\text { work }\end{array}$ & $\begin{array}{c}\text { Impact on the } \\
\text { environment }\end{array}$ \\
\cline { 2 - 6 } & $\left(€^{*} 10^{6}\right)$ & $\left(€^{*} 10^{3}\right)$ & $\begin{array}{c}\text { (trains per } \\
\text { days) }\end{array}$ & (points) & (points) \\
\cline { 2 - 6 } & - & - & + & + & + \\
\hline I & 653 & 591 & 32.7 & 20 & 50 \\
\hline II & 530 & 585 & 31.1 & 30 & 55 \\
\hline
\end{tabular}

- Construction Investments is defined by monetary units (M EUR), and it is necessary to minimize in the multi criteria analysis.

- Cost management and maintenance of the route criterion is defined by monetary units $(€)$, ie it is a sum of money obtained by discounting the annual costs over a period of time analyzed in the project (usually 30 years) and it is necessary to minimize the same in the multi criteria analysis.

- The track capacity criterion is assessed by number of pairs of trains or number of trains per shift. Greater value means that the variant is better ranked ie. the maximization of the criterion is carried out.

- Due to the inability to determine the exact duration of construction works in years, based on certain tests carried out, it has come to the conclusion that it will be more reliable if the value of this criterion is assessed descriptively, with points from 0 to 100 , where greater value means better ranked variant in relation to this criterion.
- The environmental impact analysis takes into account any possible changes, negative or positive, on the biological, physico-chemical and socioeconomic aspects of the environment (including the aspects of the health of the population living or working in the project scope ) that may arise from the implementation of the project. Experts with appropriate professional expertise and experience have made an assessment of all media and areas under consideration included in the scope of the assessment of the impacts on the environment. The Environmental Impact criterion is assessed descriptively by ranking a scale with measuring values from 0 to 100 where greater value means better ranked variant in relation to this criterion.

\section{METHODS}

\subsection{WEIGHTED SUM MODEL - WSM}

Indecision theory, theweighted sum model (WSM) is the best known and simplest multi-criteria decision analysis (MCDA)/multi-criteria decision making method for evaluating a number of alternatives in terms of a number of decision criteria. It is very important to state here that it is applicable only when all the data are expressed in exactly the same unit. In general, suppose that a given MCDA problem is defined on alternatives and decision criteria. Furthermore, let us assume that all the criteria are benefit criteria, that is, the higher the values are, the better it is. Next suppose that wj denotes the relative weight of importance of the criterion $\mathrm{Cj}$ and aij is the performance value of alternative $\mathrm{Ai}$ when it is evaluated in terms of criterion $\mathrm{Cj}$. Then, the total (i.e, when all the criteria are considered simultaneously) importance of alternative $\mathrm{Ai}$, denoted as AiWSM-score, is defined as follows:

$$
A_{i}^{\text {WSM-score }}=\sum_{j=1}^{n} w_{j} a_{i j}, \text { for } i=1,2,3, \ldots, m \text {. }
$$

For the maximization case, the best alternative is the one that yields the maximum total performance value.

\subsection{ANALYTIC HIERARCHY PROCESS}

Analytic Hierarchy Process (AHP) is a structured technique for organizing and analyzing complex decisions, based on mathematics and psychology. It was developed by Thomas L. Satty in the 1970s and has been extensively studied and refined since then.

Users of the AHP first decompose their decision problem into a hierarchy of more easily comprehended sub - problems, each of which can be analysed independently. The elements of the hierarchy can relate to any aspect of the decision problem - tangible or 
intangible, carefully measured or roughly estimated, well or poorly understood - anything at all that applies to the decision at hand. Once the hierarchy is build, the decision makers systematically evaluate its various elements by comparing them to each other two at a time, with respect to their impact on an element above them in the hierarchy.

Once the hierarchy is built, the decision makers systematically evaluate its various elements by comparing them to each other two at a time, with respect to their impact on an element above them in the hierarchy. In making the comparisons, the decision makers can use concrete data about the elements, but they typically use their judgments about the elements' relative meaning and importance. It is the essence of the AHP that human judgments, and not just the underlying information, can be used in performing the evaluations.

\subsection{VIKOR METHOD}

VIKOR method is a multi - criteria decision making or multi - criteria decision analysis method. It was originally developed by Serafim Opricovic to solve decision problems with conflicting and noncommensurable (different units) criteria, assuming that compromise is acceptable for conflict resolution, the decision maker wants a solution that is the closest to the ideal, and the alternatives are evaluated according to all established criteria. VIKOR ranks alternatives and determines the solution named compromise that is the closest to the ideal.

The compromise ranking of VIKOR has the four steps that $\mathrm{n}$ and $\mathrm{m}$ are the number of criteria and alternatives, respectively. Step 1 and 2 finds utility measure and regret measure for alternatives regarding each criterion. Then, step 3 computes the minimum and maximum amounts of the step 2 results. The calculation of $\mathrm{Qj}$ as the majority agreement in step 4 prioritizes the alternatives.

\section{RESULTS}

\subsection{WEIGHTED SUM MODEL - WSM}

Since the criteria are given in their natural scale, it is necessary to make normalization of the criteria, ie reduction of natural measuring matrix to zero matrix.

Table 2. Zero multi-criteria matrix

\begin{tabular}{|c|c|c|c|c|c|}
\hline \multirow{2}{*}{ Alternative } & \multicolumn{5}{|c|}{ Criteria } \\
\cline { 2 - 6 } & $\begin{array}{c}\text { Construction } \\
\text { Investments }\end{array}$ & $\begin{array}{c}\text { Cost } \\
\text { management } \\
\text { and } \\
\text { maintenance } \\
\text { of the route }\end{array}$ & Capacity & $\begin{array}{c}\text { Duration of } \\
\text { construction } \\
\text { work }\end{array}$ & $\begin{array}{c}\text { Impact on the } \\
\text { environment }\end{array}$ \\
\cline { 2 - 6 } & - & - & + & + & + \\
\hline I & 0.81 & 0.99 & 1.00 & 0.67 & 0.91 \\
\hline II & 1.00 & 1.00 & 0.95 & 1.00 & 1.00 \\
\hline coefficient & $\mathbf{3 2 . 5 0 \%}$ & $\mathbf{1 8 . 0 0 \%}$ & $\mathbf{2 2 . 5 0 \%}$ & $\mathbf{1 4 . 0 0 \%}$ & $\mathbf{1 3 . 0 0 \%}$ \\
\hline
\end{tabular}

When making the zero matrix it is important to define if the criteria is best rated with maximum or minimum value, ie to ascertain whether to make maximization or minimization of criteria. Zero multi criteria matrix is shown in the following table.

Since the zero multicriteria matrix has been calculated, next step is to calculate the global sum for each alternative and select an optimal alternative solution:

$$
\begin{aligned}
160 \_24 \mathrm{~d}= & 0.81 * 32.50 \%+0.99 * 18.00 \%+1.00 * 22.50 \% \\
& +0.67 * 14.00 \%+0.91 * 13.00 \%=\mathbf{0 . 8 8} \\
120 \_24 \mathrm{~s}= & 1.00 * 32.50 \%+1.00 * 18.00 \%+0.60 * 22.50 \% \\
& +1.00 * 14.00 \%+1.00 * 13.00 \%=\mathbf{0 . 9 9}
\end{aligned}
$$

Following the calculations for each alternative, it is evident that alternative 120_24s has higher global sum than alternative 160_24d, which means that alternative 120_24s is higher ranked alternative, ie according to the terms of considered criteria and obtained weight coefficients, it is recommend the choice of variant 120_24d in the process of further design.

\subsection{ANALYTIC HIERARCHY PROCESS}

Step 1. Calculate the selected criteria for assessing project performance.

Table 3. Criteria in natural scale

\begin{tabular}{|c|c|c|c|c|c|}
\hline \multirow{4}{*}{ Alternative } & \multicolumn{5}{|c|}{ Criteria } \\
\cline { 2 - 6 } & $\begin{array}{c}\text { Construction } \\
\text { Investments }\end{array}$ & $\begin{array}{c}\text { Cost } \\
\text { management } \\
\text { and } \\
\text { maintenance } \\
\text { of the route }\end{array}$ & Capacity & $\begin{array}{c}\text { Duration of } \\
\text { construction } \\
\text { work }\end{array}$ & $\begin{array}{c}\text { Impact on the } \\
\text { environment }\end{array}$ \\
\cline { 2 - 6 } & $\left(€^{*} 10^{6}\right)$ & $\left(€^{*} 10^{3}\right)$ & $\begin{array}{c}\text { (trains per } \\
\text { days) }\end{array}$ & (points) & (points) \\
\cline { 2 - 6 } & - & - & + & + & + \\
\hline I & 653 & 591 & 32.7 & 20 & 50 \\
\hline II & 530 & 585 & 31.1 & 30 & 55 \\
\hline
\end{tabular}

Step 2. Analysis of individual criteria and determing their weight coefficients

A 1

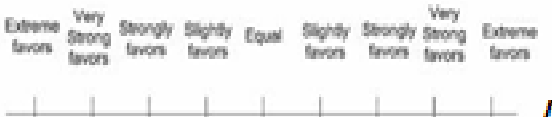

$$
\begin{array}{lllllllll}
9 & 7 & 5 & 3 & 1 & 3 & 5 & 7 & 9
\end{array}
$$

\section{Figure 1 - Table of Satty}

The analysis are done for each criteria separately, depending on the values that has given appropriate criterion for alternatives.

For this analysis is very important to determine whether the observed criteria is most favourable when it has maximum or minimum value, ie to determine whether it is necessary the criteria to be maximized or minimized. 
- $\mathrm{K} 1$ - Investment for the construction

\begin{tabular}{|l|l|l|l|l|}
\hline Alternative & I & II & SUM & $\begin{array}{l}\text { Average } \\
\text { value }\end{array}$ \\
\hline I & $\mathbf{1 . 0 0}$ & $\mathbf{0 . 2 0}$ & $\mathbf{1 . 2 0}$ & $\mathbf{0 . 1 7}$ \\
\hline II & $\mathbf{5 . 0 0}$ & $\mathbf{1 . 0 0}$ & $\mathbf{6 . 0 0}$ & $\mathbf{0 . 8 3}$ \\
\hline$\sum$ & $\mathbf{6 . 0 0}$ & $\mathbf{1 . 2 0}$ & $\mathbf{7 . 2 0}$ & $\mathbf{1 . 0 0}$ \\
\hline
\end{tabular}

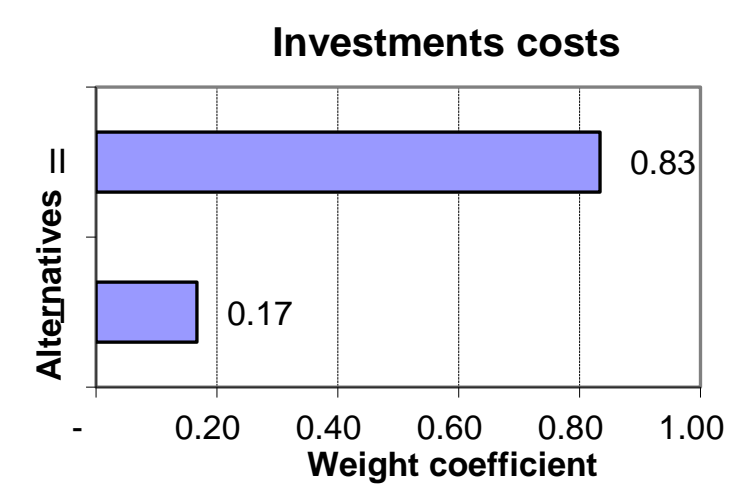

Figure 2 - Coefficients for Investments cost

- K2 - Management and maintenance costs

\begin{tabular}{|l|l|l|l|l|}
\hline Alternative & I & II & SUM & $\begin{array}{l}\text { Average } \\
\text { value }\end{array}$ \\
\hline I & 1.00 & 3.00 & $\mathbf{4 . 0 0}$ & $\mathbf{0 . 7 5}$ \\
\hline II & 0.33 & 1.00 & 1.33 & $\mathbf{0 . 2 5}$ \\
\hline$\sum$ & 1.33 & $\mathbf{4 . 0 0}$ & $\mathbf{5 . 3 3}$ & $\mathbf{1 . 0 0}$ \\
\hline
\end{tabular}

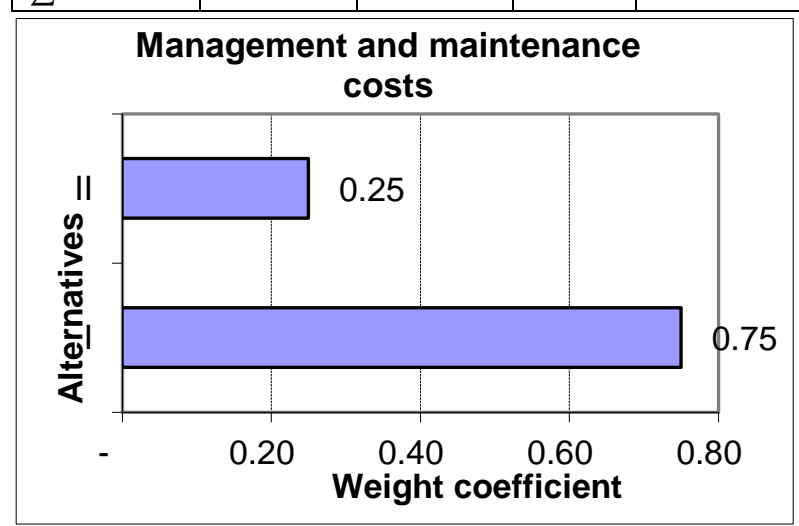

Figure 3 - Coefficients for Management and maintenance cost

- K3 - Capacity

\begin{tabular}{|l|l|l|l|l|}
\hline Alternative & I & II & SUM & Average value \\
\hline I & 1.00 & 5.00 & $\mathbf{6 . 0 0}$ & $\mathbf{0 . 8 3}$ \\
\hline II & 0.20 & 1.00 & $\mathbf{1 . 2 0}$ & $\mathbf{0 . 1 7}$ \\
\hline$\sum$ & 1.20 & $\mathbf{6 . 0 0}$ & $\mathbf{7 . 2 0}$ & $\mathbf{1 . 0 0}$ \\
\hline
\end{tabular}

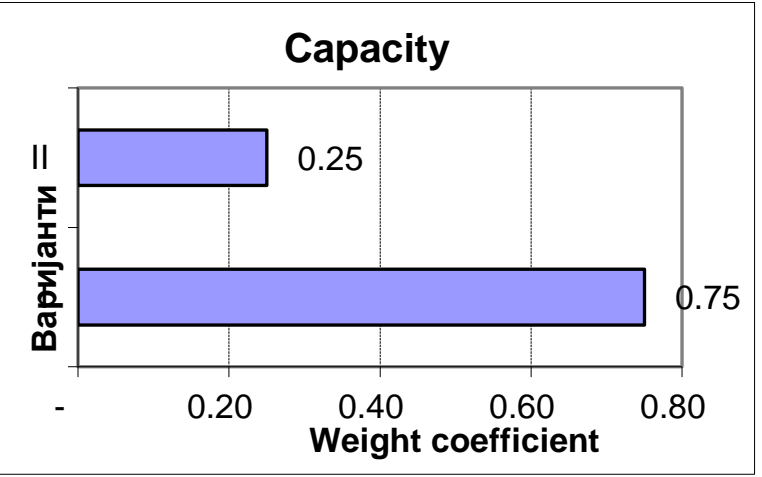

Figure 4-Coefficients for Capacity

- $\mathrm{K} 4$ - Duration of construction work

\begin{tabular}{|l|l|l|l|l|}
\hline Alternative & I & II & SUM & Average value \\
\hline I & 1.00 & 2.00 & $\mathbf{3 . 0 0}$ & $\mathbf{0 . 6 7}$ \\
\hline II & 0.50 & 1.00 & $\mathbf{1 . 5 0}$ & $\mathbf{0 . 3 3}$ \\
\hline$\Sigma$ & $\mathbf{1 . 5 0}$ & $\mathbf{3 . 0 0}$ & $\mathbf{4 . 5 0}$ & $\mathbf{1 . 0 0}$ \\
\hline
\end{tabular}

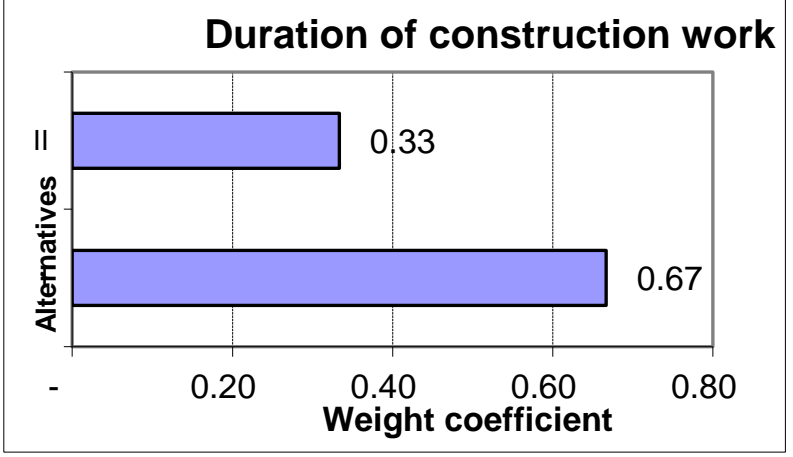

Figure 5 - Coefficients for Duration of construction work

- $\quad \mathrm{K} 5$ - Impact on the environment

\begin{tabular}{|l|l|l|l|l|}
\hline Alternative & I & II & SUM & Average value \\
\hline I & 1.00 & 2.00 & 3.00 & 0.67 \\
\hline II & 0.50 & 1.00 & 1.50 & 0.33 \\
\hline$\sum$ & 1.50 & 3.00 & 4.50 & 1.00 \\
\hline
\end{tabular}

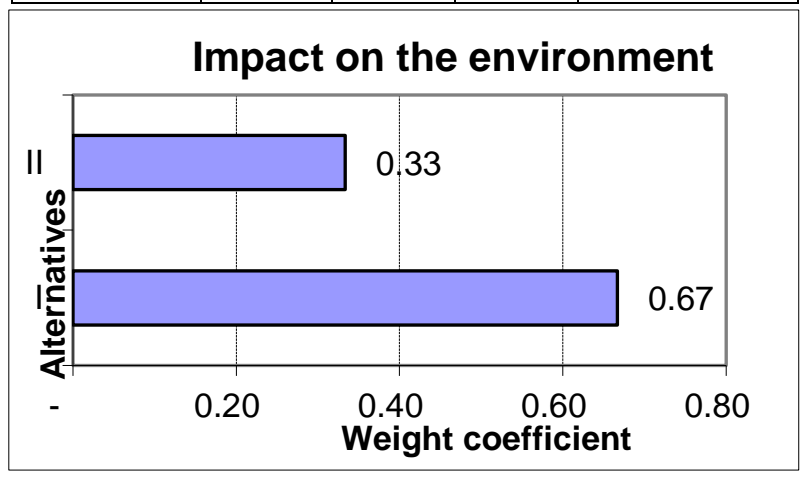

Figure 6-Coefficients for Impact on the environment 


\section{Step 3. Creating comparison matrix}

Considering the defined purpose, for each pair of criteria should be submitted value of importance of one criteria over another in the evaluation matrix (comparison).

\section{Table 4. sorting matrix}

\begin{tabular}{|c|c|c|c|c|c|c|c|}
\hline 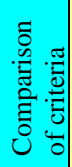 & К1 & К2 & К3 & К4 & К5 & $\sum_{n}$ & 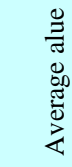 \\
\hline K1 & 1.00 & 5.00 & 3.00 & 7.00 & 7.00 & 23.00 & 0.430 \\
\hline K2 & 0.20 & 1.00 & 3.00 & 3.00 & 4.00 & 11.20 & 0.209 \\
\hline К3 & 0.33 & 0.33 & 1.00 & 3.00 & 7.00 & 11.67 & 0.218 \\
\hline K4 & 0.14 & 0.33 & 0.33 & 1.00 & 4.00 & 5.81 & 0.109 \\
\hline К5 & 0.14 & 0.25 & 0.14 & 0.25 & 1.00 & 1.79 & 0.033 \\
\hline
\end{tabular}

Table 5. normalized sorting matrix

\begin{tabular}{|c|c|c|c|c|c|c|c|}
\hline 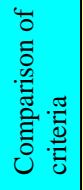 & K1 & К2 & К3 & К4 & К5 & 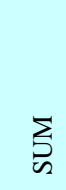 & 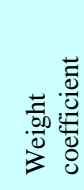 \\
\hline К1 & 0.55 & 0.72 & 0.40 & 0.49 & 0.30 & 2.47 & 0.494 \\
\hline К2 & 0.11 & 0.14 & 0.40 & 0.21 & 0.17 & 1.04 & 0.208 \\
\hline К3 & 0.18 & 0.05 & 0.13 & 0.21 & 0.30 & 0.88 & 0.176 \\
\hline К4 & 0.08 & 0.05 & 0.04 & 0.07 & 0.17 & 0.42 & 0.083 \\
\hline К5 & 0.08 & 0.04 & 0.02 & 0.02 & 0.04 & 0.19 & 0.039 \\
\hline
\end{tabular}

Step 4. Calculation with combined weighted with weight coefficients

The combined weighted with weight coefficients is done by taking the weight ratios of each criteria provided in table 7.17 and the weight coefficients obtained for each criteria separately with his comparison in terms of both alternatives, which are presented in the above tables and graphs.

The final score and ranking are calculated according following steps: weighting criteria obtained for each criteria separately in the analysis of two alternative solutions. Finally weighted coefficients are summed and the final results are calculated, based of which can be done ranking of alternative solutions.
Table 6. Final score

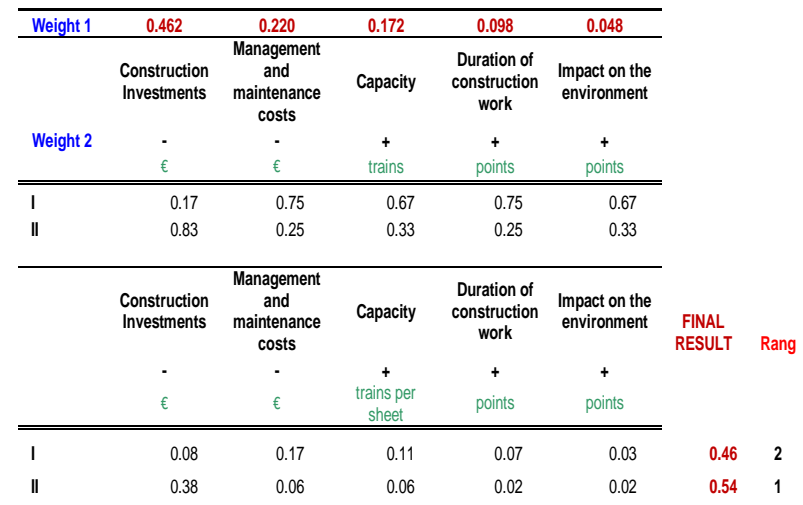

From the performed calculations by AHP method, it is evident that alternative 120_24s is better solution than alternative 160_24d.

Table 7. Initial decision matrix

\section{VIKOR method}

\begin{tabular}{|c|c|c|c|c|c|}
\hline \multirow{2}{*}{$\begin{array}{l}\text { Alter- } \\
\text { native }\end{array}$} & \multicolumn{5}{|c|}{ Criteria } \\
\hline & $\begin{array}{l}\mathrm{K}_{1} \\
\left(€^{*} 10^{6}\right)\end{array}$ & $\begin{array}{l}\mathrm{K}_{2} \\
\left(€^{*} 10^{3}\right)\end{array}$ & $\begin{array}{l}\mathrm{K}_{3} \\
\text { (trains) }\end{array}$ & $\begin{array}{l}\mathrm{K}_{4} \\
\text { (points) }\end{array}$ & $\begin{array}{l}\mathrm{K}_{5} \\
\text { (points) }\end{array}$ \\
\hline I & 1.00 & 1.00 & 0.00 & 1.00 & 1.00 \\
\hline II & 0.00 & 0.00 & 1.00 & 0.00 & 0.00 \\
\hline fi* & 530.00 & 585.00 & 32.7 & 30 & 55 \\
\hline fi- & 653.00 & 591.00 & 31.1 & 20 & 50 \\
\hline $\mathrm{Di}$ & -123.00 & -6.00 & 1.6 & 10 & 5 \\
\hline
\end{tabular}

For further implementation of multi - criteria decision making is required that all criteria can be assigned relative weights or weight factors that determine their meaning. In this analysis to define the weighting method used for the simulation of structural preferences, so that for the values of the weight coefficients are proposed five scenarios:

- Scenario I: All of the criteria have the same importance, so they have same weight ratio.

- Scenario II: Priority is given to the economic and transport criteria, so that the heist value of weighting is given to the criteria $\mathrm{K} 1, \mathrm{~K} 2$ and $\mathrm{K} 3$, and lowest value of the criteria K4 and K5.

- Scenario III: Priority is given to the economic aspect, so that the highest value of weighting is goven to the criteria $\mathrm{K} 1$ and $\mathrm{K} 2$, and lowest to the criteria $\mathrm{K} 4$ and $\mathrm{K} 5$.

- Scenario IV: Priority is given to traffic aspect and the highest value of weighting is given to criterion K3.

- Scenario V: Priority is given to the environmental aspect, so the highest value of the weighting is given to the criteria $\mathrm{K} 4$ and $\mathrm{K} 5$. 
Table 8. Alues of the weight coefficients for the proposed scenarios

\begin{tabular}{|c|c|c|c|c|c|}
\hline \multirow{2}{*}{$\begin{array}{l}\text { Weight } \\
\text { Coefficients }\end{array}$} & \multicolumn{5}{|c|}{ Scenarios } \\
\hline & SC1 & $\mathrm{SC} 2$ & SC3 & $\mathrm{SC} 4$ & SC5 \\
\hline $\mathrm{w}_{1}$ & 1 & 3 & 3 & 2 & 2 \\
\hline $\mathrm{w}_{2}$ & 1 & 3 & 3 & 2 & 2 \\
\hline $\mathrm{w}_{3}$ & 1 & 3 & 2 & 3 & 2 \\
\hline $\mathrm{w} 4$ & 1 & 2 & 2 & 2 & 3 \\
\hline w5 & 1 & 2 & 1 & 1 & 3 \\
\hline
\end{tabular}

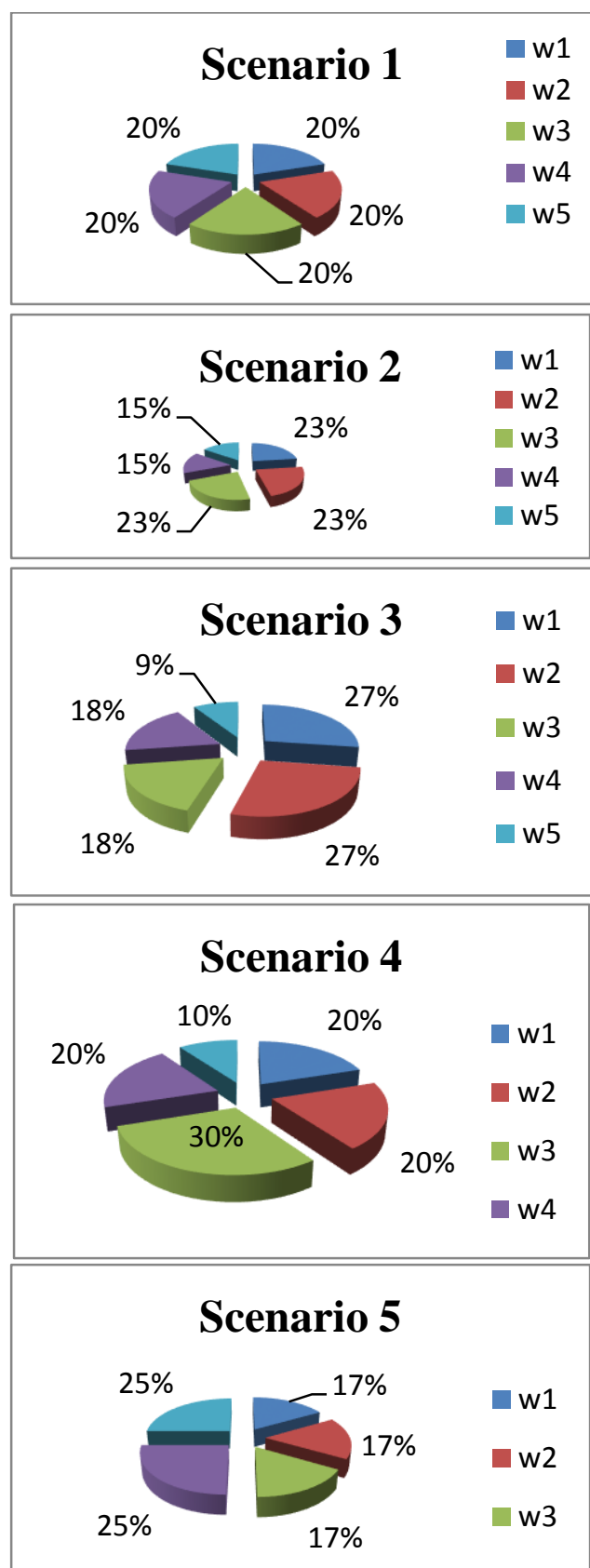

Figure 7 - Graphic representation of weight ratios obtained by the method VIKOR
Based on fundamental relations of the program package VIKOR and adopted weight for strategy making, $v=0.5$ has been obtained the following final decision matrix and ranking.

Table 9. Decision matrix based on indicators Qj, QSj and $Q R j$

\begin{tabular}{|l|l|l|l|}
\hline \multirow{4}{*}{ SC 1 } & & $\mathrm{I}$ & $\mathrm{II}$ \\
\hline \multirow{5}{*}{ SC 2 } & $\mathbf{Q}_{\mathbf{j}}$ & $\mathbf{0 , 5}$ & $\mathbf{0 , 5}$ \\
\cline { 2 - 4 } & $\mathrm{QS}_{\mathrm{j}}$ & 1,0 & 0,0 \\
\cline { 2 - 4 } & $\mathrm{QR}_{\mathrm{j}}$ & 0,5 & 0,5 \\
\hline \multirow{5}{*}{$\mathrm{SC} 3$} & $\mathbf{Q}_{\mathbf{j}}$ & $\mathbf{1 , 0}$ & $\mathbf{0 , 0}$ \\
\cline { 2 - 4 } & $\mathrm{QS}_{\mathrm{j}}$ & 1,0 & 0,0 \\
\cline { 2 - 4 } & $\mathrm{QR}_{\mathrm{j}}$ & 1,0 & 0,0 \\
\hline \multirow{5}{*}{ SC 4 } & $\mathbf{Q}_{\mathrm{j}}$ & $\mathbf{1 , 0}$ & $\mathbf{0 , 0}$ \\
\cline { 2 - 4 } & $\mathrm{QS}_{\mathrm{j}}$ & 1,0 & 0,0 \\
\cline { 2 - 4 } & $\mathrm{QR}_{\mathrm{j}}$ & 1,0 & 0,0 \\
\hline \multirow{5}{*}{ SC 5 } & $\mathbf{Q}_{\mathbf{j}}$ & $\mathbf{0 , 5}$ & $\mathbf{0 , 5}$ \\
\cline { 2 - 4 } & $\mathrm{QS}_{\mathrm{j}}$ & 1,0 & 0,0 \\
\cline { 2 - 4 } & $\mathrm{QR}_{\mathrm{j}}$ & 0,0 & 1,0 \\
\hline & $\mathbf{Q}_{\mathrm{j}}$ & $\mathbf{1 , 0}$ & $\mathbf{0 , 0}$ \\
\cline { 2 - 4 } & $\mathrm{QS}_{\mathrm{j}}$ & 1,0 & 0,0 \\
\cline { 2 - 4 } & $\mathrm{QR}_{\mathrm{j}}$ & 1,0 & 0,0 \\
\hline
\end{tabular}

Table 10. Ranked list of alternative solutions for the route of the proposed scenarios

\begin{tabular}{|c|c|c|c|c|c|}
\hline \multirow[t]{2}{*}{ Ranging } & \multicolumn{5}{|c|}{ Scenarios } \\
\hline & СЦ I & СЦ II & СЦ III & СЦ IV & СЦ V \\
\hline 1 & $\begin{array}{l}120 \_24 \mathrm{~s} \\
(0,5)\end{array}$ & $\begin{array}{l}120 \_24 \mathrm{~s} \\
\text { (0) }\end{array}$ & $\begin{array}{l}120 \_24 \mathrm{~s} \\
(0)\end{array}$ & $\begin{array}{l}120 \_24 \mathrm{~s} \\
(0,5)\end{array}$ & $\begin{array}{l}120 \_24 \mathrm{~s} \\
\text { (0) }\end{array}$ \\
\hline 2 & $\begin{array}{l}160 \_24 d \\
(0,5)\end{array}$ & $\begin{array}{l}160 \_24 d \\
(1)\end{array}$ & $\begin{array}{l}160 \_24 d \\
\text { (1) }\end{array}$ & $\begin{array}{l}160 \_24 d \\
(0,5)\end{array}$ & $\begin{array}{l}160 \_24 d \\
(1)\end{array}$ \\
\hline
\end{tabular}

The results of the ranking show that alternative $120 \_24 \mathrm{~s}$ is more favourable alternative solution for scenarios 2, 3 and 5, while scenarios 1 and 4 rang both alternatives as same. Summing the results we have come up with a solution that better solution is alternative 120_24s and it is proposed as a compromise solution.

\section{CONCLUSION}

Finally this paper was intended to achieve several goals. First was described the application of multi criteria analysis in making decision to select the best route for a railroad. Second, multi - criteria analysis were applied on a present case to choose the route for the rail using three different methods (Weight Sum Method, AHP methos and VIKOR method).

The problem under consideration in this thesis is solved by the application of multi criteria analysis, by 
applying several criteria and alternatives. It is known that there are many developed methods and techniques for multi criteria decision making. In order to make a good decision, it is necessary to evaluate the alternatives by defining the appropriate criteria. It is also necessary to define weight ratios for each of the criteria. The decision-making process is complex because of the presence of conflicting objectives between the available criteria and alternatives, so it's difficult to choose an alternative that best suits the set of goals. Therefore, three methods of multi criteria analysis have been applied in order to obtain more reliable and reliable results. From the analyses and calculations the following results were obtained:

Table 11. Tabular presentation of the results

\begin{tabular}{|l|l|l|l|l|}
\hline ALTERNATIVE & WSM & AHP & VIKOR & RANG \\
\hline I & 0.88 & 0.44 & 1 & $\mathbf{2}$ \\
\hline II & 0.99 & 0.56 & 0 & $\mathbf{1}$ \\
\hline
\end{tabular}

If we take a look at the practical application of the three methods for multicriteria analysis, it can be concluded that they are a tool that really is of considerable help when the task is to decide on the choice of the most favorable variant solution in relation to several criteria. Regarding the applied methods, from the calculations made, it is evident that all methods give the same result, that is, from the conducted multicriterial analysis after all three considered methods, the result is that the alternative II is a better alternative than I in different criteria that are taken into account.

However, if you look at the methodology of problem solving using the methods applied in this thesis, it is obvious that they have different principles and methodologies for decomposing and solving the problem. If you ask analysts dealing with this question, which of the methods is best, you can get different answers depending on the type of problem to be solved, and the type of solution to be obtained.

Based on the foregoing it can be concluded that multi - criteria analysis represent a flexible solution intended for users who can successfully use only with a specific definition of the appropriate criteria and alternatives.

\section{REFERENCES}

[1] Anderson, D. R, Sweeney D. J, Williams T. A, An Introduction to Management Science: Quantitative Approches to Decision Making, South - Western College Publishing, 2000.
[2] Arditi D, Singh S, Selection criteria for commercially available software in constructing accounting, Project Management 9 (1) 39-44, 1991.

[3] Avkiran N. K, Decomposing technical efficiency and window analysis. Studies in Economics and Finance, 22(1), 61-91, 2004.

[4] Barić D, Radačić Ž, Čuperić D, (): Implementation of multicriteria deciosion-making method in selecting the railway line for reconstruction, Proceedings book ICTS 2006 Transportation and Globalization, ur. Zanne M, Fabjan D, Janček P, Fakultet za pomorstvo in promet Portorož, Portorož, 2006.

[5] Borović S, Nikolić I, Višekriterijumska optimizacija: metode, primena u logistici, softver, Centar vojnih škola Vojske Jugoslavije, Beograd, 1996.

[6] Bana e Costa C and Vansnick J, A critical analysis of the eigenvalue methodused to derive priorities in AHP. European Journal of Operational Research 187(3): 1422-1428, 2008.

[7] Bristow A. L, Nellthorp J, Transport project appraisal in the Eurpean Union, Transport Policy, Elsevier, Vol 7, no. 1, pp. 51- 60, 2000.

[8] Cristóbal J. R. S, Biezma M. V, Martínez R, Somoza $\mathrm{R}$, Selection of materials under aggressive environments: The VIKOR method, 3rd International Conference on Integrity, Reliability and Failure, Porto/Portugal, 2009.

[9] Čupić E. M, Rao Tummala V. T, Savremeno odlučivanje-Metode $i$ primena, Naučna knjiga, Beograd, 1997.

[10]Grupa autora, Studija podobnosti modernizacije železničke pruge Subotica-Beograd-Niš-Dimitrovgrad: Bankarski dosije, Saobraćajni institut CIP, Sofrerail Paris, Beograd, 1991.

[11]Greco S, Multiple Criteria Decision Analysis: State of the Art Surveys, International Series in Operations Research \& Management Science, Springer, Vol. 78, New York, 2005.

[12]Hunjak T, Jakovčević D, Višekriterijski modeli za rangiranje $i$ uspoređivanje banaka, Zbornik Ekonomskog fakulteta, 2003.

[13]Iniestra J. G, Gutierrez J. G, Multicriteria decisions on interdependent infrastructure transportation projects using an evolutionary-based framework, Applied Soft Computing, Elsevier, Vol.9., No. 2., pp. 512-526, 2009.

[14]Jovanović P, Upravljanje investicijama, Beograd: FON, 1997. 
[15]Jugović T. P, Baričević H, Karleuša B, (): Višekriterijska optimizacija konkurentnosti paneuropskog koridora Vb, Promet - Traffic \& Transportation, Vol. 18, No. 3, pp. 189-195, 2006.

[16]Kosijer M, Ivić M, Marković M, Belošević I, (): Višekriterijsko odlučivanje u planiranju I projektiranju trase željezničke pruge, GRAĐEVINAR, Vol. 64, No. 3, pp. 195-205, 2012.

[17]Кракутовски 3, Методи за евалуација на проекти од транспортната инфраструктура, Градежен Факултет, Скопје, 2015.

[18]Karleuša B, Ožanić N, Određivanje prioriteta $u$ realizaciji vodnogospodarskih planova, Građevinar 63, 2, 151-161, 2011.

[19]Kwak N, K, Lee C, A multicriteria decision-making approach to university resource allocations and information infrastructure planning, European Journal of Operational Research 110, 1998.

[20]Margeta J, Prskalo G, Izbor lokacije za sanitarno odlagalište, Građevinar 58, 12, 997-1008, 2006.

[21]Mladineo N. i dr, Izbor trase jadranske autoceste primjenom metode višekriterijalne analize, Zbornik radova SYM-OP-IS, Kupari, 651-654, 1990.

[22]Maggie C. Y. T. and Tummala, V. M. R, An application of the AHP invendor selection of a telecommunications system, Omega, 29 171-182, 2001.

[23]Mendoza G. A, Martins H, Multi-criteria decision analysis in natural resource management: A critical review of methods and new modelling paradigms, Forest Ecology and Management, Elsevier, Vol. 230, No. 1-3., pp. 1-22, 2006.

[24]Nikolić I, Borović S, Višekriterijska optimizacija: metode, primjena u logistici, softver, Centar vojnih škola Vojske Jugoslavije, Beograd, 1996.

[25]Opricović S, Višekriterijumska optimizacija sistema u građevinarstvu, Građevinski fakultet, Beograd, 1998.

[26]Opricovic S, A compromise solution in water resources planing, Water Resour Manage, 15491561, 2009.

[27]Peniwati K, The analytic hierarchy process: the possibility for group decision making. In: Proceedings of the 4th international symposium on the analytic hierarchy process, Vancouver, Canada. (Obtainable from RWS Publications, 4922 Ellsworth Avenue, Pittsburgh, PA 15213.), pp 202-214, 1996.

[28]Sahely H. R, Kenedy C. A, Adams B. J, Developing sustainability criteria for urban infrastructure systems, Canadian Journal of Civil Engineering,
NRC Research Press, http://www.nrcresearchpress.com/, Canada, Vol. 32., No.1, pp. 72-85, 2005.

[29]Saaty T. L, Vargas L. G, Models, Methods, Concepts \& Applications of the Analytic Hierarchy Process, Kluwer Academic Publishers, Dordrecht, 2001.

[30] Saaty T. L, Fundamentals of Decision Making and Priority Theory with AHP, Pittsburgh: RWS Publications, 1994.

[31]Saaty T, How to make decision : The Analytic Hierarchy Process. European Journal of Opertional Research 48 (1990) 9-26 North-Holand, 1990.

[32]Saaty T. L, The Analytic Hierarchy Process, drugo izdanje, RWS Publications, Pittsburg, 1996.

[33]Šošić I, Primijenjena statistika, Zagreb: Školska knjiga, 2004.

[34]Talvitie A, Evaluation of road projects and programs in developing countries, Transport Policy, Elsevier, Vol. 7, No. 1, pp. 61-72, 2000.

[35]Triantaphyllou E, Multi-criteria decision making methods: A comparative study, Kluwer Academic Publishers, Nederlands, 2000.

[36]Tudela A, Akiki N, Cisternas R, Comparing the output of cost benefit and multi-criteria analysis: An application to urban transport investments, Transportation Research Part A: Policy and Practice, Elsevier, Vol. 40, No. 5., pp. 414-423, 2006.

[37]Van Horne J. C, Wachowicz J. M, Fundamentals of financial management, 13th edition, New Jersey: Prentice Hall imprint, 2008.

[38]Vargas L, An overview of the analytic hierarchy process and its applications. European Journal of Operational Research 48(1): 2-8, 1990.

[39]Vreeker R, Nijkamp P, Welle C. T, A multicriteria decision support methodology for evaluating airport expansion plans, Transportation Research Part D: Transport and Environment, Elsevier, Vol 7, no. 1, pp. 27-47, 2002.

[40]Winston W, Albright C, Practical management science, Revised Third Edition, London: Thomson South-Western, 2008..

[41]Willis K. G, Garrod G. D, Harvey D. R, A review of cost-benefit analysis as applied to the evaluation of new road proposals in the U.K., Transportation Research part D: Transport and Environment, Elsevier, Vol. 3, , No. 3, pp. 141-156, 1998.

[42]Weng S. Q, Huang G. H, Li Y. P, An integrated scenario-based multi-criteria decision support system for water resources management and planning-A case study in the Haihe River Basin, Experts Systems with 
Applications, Elsevier, Vol. 37., No.12. ,pp. $8242-$ 8254, 2010.

[43]Weber C. A, Current, J. R. and Benton W. C, "Vendor Selection Criteria and Methods", European Journal of Operational Research, 50 2-18, 1991.

[44] Zeleny M, Multiple citeria decision making. McGraw-Hill Book Company, New York, 1982.
[45] Zahedi F, Database management system evaluation and selection decisions,Decision Sciences 16 (1) 91116, 1998.

[46]Zahedi F, A method for quantitative evaluation of expert systems, European Journal of Operational Research 48 (1) 136-147, 1990.

[47][Final Feasibility Report for the railway sections along the Corridor X, Skopje, 2013.

\section{REZIME}

\section{UVOĐENJE RAZLIČITIH METODA MULTIKRITERIJUMSKE ANALIZE ZA EVALUACIJU I KRITIČKO UPOREĐIVANJE NA PROJEKTIMA SAOBRAĆAJNE INFRASTRUKTURE}

Donošenje odluka je studija identifikovanja i izbora alternativa, sa ciljem pronalaženja najboljeg rešenja baziranog na različitim faktorima i uzimajući u obzir očekivanja donosioca odluka. Svaka odluka se donosi u okruženju donosica odluka, koje je definisano kao skup informacija, alternativa, vrednosti i preferenci (prednosti) dostupnih u vremenu kad odluke treba da se donesu. Složena tačka u donošenju odluka je mnogobrojnost kriterijuma koji se koriste za procenu alternativa. Ciljevi su često konfliktni $i$ u većini slučajeva u proces odlučivanja su uključene različite grupe eksperata. Da bi se pojednostavile ove analize postoje "multikriterijumske metode odlučivanja“ radi potrebe da se ima formalizovani metod koji će pomoći pri odlučivanju u situacijama koje uključuju višse kriterijuma.

U radu je prikazana metodologija izbora trase u procesu planiranja i projektovanja železničke pruge koja se temelji na metodama višekriterijumskog odlučivanja. Predložena metodologija omogućava celovito i sistemsko rešavanje ovog problema, čiji krajnji rezultat treba da bude predlog najpovoljnije trase u skladu sa usvojenim kriterijumima i realnim ograničenjima. Razvijena metodologija je bazirana na metodi kompromisnog rangiranja (WSM, AHP I VIKOR metoda), a njeno testiranje izvršeno je na primeru izbora jedne od dve varijante trase železničke pruge na deonici Koridora X, između stanica Dracevo (Skopje) i stanica Veles. Dobijeni rezultati su pokazali praktičnu primenu ove metodologije.

Ključne reči: planiranje i projektovanje, železnička pruga, najbolja trasa železničke pruge, multikriterijumske metode, WSM, AHP metoda, VIKOR metoda 